\title{
Prawo do udziału tłumacza jako jedna z przesłanek rzetelnego procesu karnego
}

\section{The Right for Interpreter Assistance as One of Premises of a Fair Penal Trial}

\author{
Dr Joanna Dhugosz* \\ KATEDRA PRAWA KARNEGO, WYDZIA£ PRAWA I ADMINISTRACJI UAM \\ jdlugosz@amu.edu.pl
}

\begin{abstract}
Abstrakt
Przedmiotem niniejszego artykułu jest ustalenie, w jakim zakresie iw oparciu o jakie przesłanki prawo do udziału tłumacza w postępowaniu karnym, wynikające $\mathrm{z}$ art. 204 Kodeksu postępowania karnego, stanowi gwarancję uczciwego i rzetelnego procesu. Z ogólnych dyrektyw uczciwego procesu karnego wynika bowiem, iż rozstrzygnięcia organów procesowych powinny być oparte na prawdziwych ustaleniach faktycznych, co z kolei nakłada na te organy obowiązek wszechstronnego (tj. zgodnego z rzeczywistością) poznania stanu faktycznego sprawy.

Wynikająca z regulacji powołanego Kodeksu zasada stanowi, że jeżeli stwierdzenie okoliczności mających istotne znaczenie dla rozstrzygnięcia sprawy wymaga wiadomości specjalnych, korzysta się $\mathrm{z}$ pomocy biegłego, a $\mathrm{w}$ uzasadnionych przypadkach $\mathrm{z}$ pomocy tłumacza. Zgodnie z obowiązującym prawem, obowiązek wezwania tłumacza istnieje przede wszystkim wówczas, gdy zachodzi potrzeba przesłuchania osoby głuchej lub niemej, a nie wystarcza porozumienie się z nią za pomocą pisma, przesłuchania osoby nie władającej językiem polskim, a także przełożenia na język polski pisma sporządzonego w języku obcym lub odwrotnie, bądź też zapoznania się $\mathrm{z}$ treścią przeprowadzanego dowodu. Udział tłumacza $w$ procesie karnym jest więc jednym ze środków dowodowych. Uczestniczący w procesie karnym tłumacz przy tym związany jest zasadą obiektywizmu, wyrazem czego jest m.in. treść przyrzeczenia, jakie składa przed przystąpieniem do swoich czynności.

Analizowane zagadnienie zostanie przedstawione także z perspektywy praw i obowiązków ciążących na tłumaczu, jako na jednym z uczestników procesu. W charakterze przykładu można tu wymienić zobowiązanie tłumacza do stawiennictwa, do mówienia prawdy, do złożenia przyrzeczenia, a także jego prawo do zachowania tajemnicy państwowej, służbowej i zawodowej z wszelkimi konsekwencjami dotyczącymi trybu zwalniania z tych tajemnic.
\end{abstract}




\section{Wprowadzenie}

Prawo do rzetelnego procesu sądowego stanowi jedno z fundamentalnych praw przysługujących każdemu obywatelowi w demokratycznym państwie prawa i jest jednocześnie gwarantem praworządności państwa oraz ochrony wszelkich praw i wolności jednostki. Prawo to stanowi przedmiot regulacji art. 45 Konstytucji RP', gwarantujący „każdej osobie prawo do sprawiedliwego i jawnego rozpatrzenia sprawy bez nieuzasadnionej zwłoki przez właściwy, niezależny, bezstronny i niezawisty sąd", a nadto zawarte jest $\mathrm{w}$ art. 6 Konwencji o Ochronie Praw Człowieka i Podstawowych Wolności², który stanowi m.in., że każdy oskarżony o popełnienie czynu zagrożonego karą ma co najmniej prawo do korzystania $\mathrm{z}$ bezpłatnej pomocy tłumacza, jeżeli nie rozumie lub nie mówi językiem używanym w sądzie (por. art. 6 ust. 3 lit. e EKPC).

$\mathrm{Na}$ prawo do rzetelnego procesu składają się następujące zasady: prawo jednostki do rozparzenia sporu prawnego przez bezstronny i niezawisły sąd, działający na podstawie ustawy; prawo jednostki do rozpatrzenia jej sprawy bez nieuzasadnionej zwłoki; zasada równości stron w procesie; zasada aktywnego udziału stron w postępowaniu; prawo do odwoływania się od wyroku do sądu wyższej instancji; zakaz powtórnego sądzenia i karania za ten sam czyn; a także prawo do informacji prawnej, $\mathrm{w}$ tym - będące przedmiotem niniejszego opracowania - prawo do korzystania z bezplatnej pomocy tłumacza, jeżeli oskarżony nie włada językiem używanym w postępowaniu.

\section{Funkcje tłumacza w postępowaniu karnym}

Udział tłumacza w postępowaniu karnym stał się już pewną rutyną. Dość znaczna liczba oskarżonych w procesie karnym, nie znających języka polskiego, bądź też nie władająca nim w stopniu wystarczającym do swobodnego porozumiewania się, czyni pomoc tłumacza konieczną i niezbędną. Jednakże już pobieżna lektura przepisów prawa polskiego, regulujących zagadnienie udziału tłumacza w polskim procesie karnym ${ }^{3}$ skłania do refleksji, iż problematyka ta należy do tego rodzaju zagadnień karnoprocesowych, które, mimo potrzeby szczegółowego uregulowania $\mathrm{w}$ powszechnie obowiązujących przepisach, w znacznej mierze nie zostały uwzględnione w inicjatywach legislacyjnych polskiego ustawodawcy.

Jak trafnie twierdzi $P$. Hofmański4, udział tłumacza w postępowaniu karnym może być analizowany w dwóch różnych kontekstach, odpowiadających funkcjom pełnionym przez tłumacza $\mathrm{w}$ danym postępowaniu. Po pierwsze, udział

\footnotetext{
*Autorka jest doktorem nauk prawnych, adiunktem w Katedrze Prawa Karnego na Wydziale Prawa i Administracji Uniwersytetu im. Adama Mickiewicza w Poznaniu oraz w Katedrze Prawa Karnego, Międzynarodowego Prawa Karnego, Komparatystyki Prawnej i Filozofii Prawa na Wydziale Prawa Uniwersytetu Europejskiego Viadrina we Frankfurcie nad Odrą.

${ }^{1}$ Konstytucja Rzeczypospolitej Polskiej z 2 kwietnia 2007 roku, Dz.U. z 1997 r., Nr 78, poz. 483.

${ }^{2}$ Konwencja z 4.11.1950 r., ratyfikowana przez Polskę 19.1.1993 r. i tego samego dnia weszła w życie. Treść Konwencji dostępna jest na stronie internetowej: http://www.echr.coe.int/NR/rdonlyres/7B5C268E-CEB3-49A5-865F06286BDB0941/o/PolishPolonais.pdf [20.05.2009] (dalej jako: Konwencja, EKPC). 3 Zob. przede wszystkim art. 72, 204 oraz 619 § 3 Kodeksu postępowania karnego.

4 Por. P. Hofmański, Prawo do udziału thumacza $w$ postępowaniu karnym, w: Przestępczość przygraniczna. Postępowanie karne przeciwko cudzoziemcom w Polsce, pod red. A.J. Szwarca, Poznań 2000, s. 147-156. Podział ten przyjmują także inni przedstawiciele doktryny, zob. np. B. Zygmont, Prawo do korzystania z bezpłatnej pomocy thumacza $w$ postępowaniu karnym $w$ świetle standardów europejskich, Państwo i Prawo 2004, Nr 7, s. 78.
} 
tłumacza w postępowaniu karnym może być podyktowany koniecznością wynikającą $\mathrm{z}$ wymagań związanych $\mathrm{z}$ gromadzeniem materiału dowodowego. W charakterze przykładu funkcjonowania tłumacza w takim właśnie charakterze, $P$. Hofmański5 przywołuje, iż nie sposób bez uprzedniej pomocy tłumacza korzystać z dokumentów sporządzonych w języku obcym czy też przesłuchiwać świadków niewładających językiem polskim. Drugi aspekt odnosi się do uprawnień procesowych, które przysługują podejrzanemu lub oskarżonemu w procesie, tzn. dana osoba może z nich korzystać tylko wówczas, gdy język, jakim posługują się pracownicy wymiaru sprawiedliwości jest dla niej zrozumiały, a także gdy potrafi się w tym języku wysłowić. W tym drugim kontekście uprawnienie do korzystania $\mathrm{z}$ pomocy tłumacza stanowi zatem jeden $\mathrm{z}$ elementów wspomnianego już powyżej prawa do rzetelnego procesu karnego $\mathrm{i}$ jest związany $\mathrm{z}$ koniecznością zagwarantowania pokrzywdzonemu i oskarżonemu możliwości korzystania w pełni $\mathrm{z}$ ich uprawnień procesowych.

Podkreślenia wymaga jednak, że komunikacja uczestniczącego w procesie obcokrajowca z organami polskiego wymiaru sprawiedliwości odbywać się może zarówno w sposób pisemny, jak i ustny. Potrzeba udziału tłumacza pojawia się jednak przede wszystkim w przypadku komunikacji ustnej.

\section{Prawo do udziału tłumacza jako jeden $z$ wymogów związanych z gromadzeniem materiału dowodowego}

Podstawą prawną regulującą omawianą problematykę na gruncie prawa polskiego są zarówno przepisy Kodeksu postępowania karnego ${ }^{6}$, jak i ustawy: Prawo o funkcjonowaniu sądów powszechnych7\%

\subsection{Regulacje Kodeksu postępowania karnego}

Problematyka udziału tłumacza w procesie karnym uregulowana jest przede wszystkim w przepisie art. 204 k.p.k. W myśl tej regulacji obowiązek wezwania tłumacza pojawia się w trzech sytuacjach. Po pierwsze, tłumacza należy wezwać, jeżeli zachodzi potrzeba przesłuchania osoby głuchej lub niemej, a nie wystarcza porozumienie się z nią za pomocą pisma (art. 204 § 1 pkt 1 k.p.k.), jak również, gdy zachodzi potrzeba przesłuchania osoby nie władającej językiem polskim (art. 204 $\S 1$ pkt 2 k.p.k.). Ponadto obowiązek wezwania tłumacza istnieje, gdy zachodzi potrzeba przełożenia na język polski pisma sporządzonego $\mathrm{w}$ języku obcym lub odwrotnie albo zapoznania oskarżonego z treścią przeprowadzanego dowodu (art. $204 \S 2$ k.p.k.).

Analizując powyższą regulację wskazać należy na obligatoryjny charakter zobowiązania do wezwania tłumacza, wskazany w $\S 1$ oraz w $\S 2$ tego przepisu. Wykładnia tej normy skłania zatem do przyjęcia, iż obowiązek wezwania tłumacza istnieje zawsze wówczas, gdy przesłuchiwana osoba językiem polskim nie włada, i to bez względu na to, czy którykolwiek z uczestników procesu (np. protokolant) zna język obcy, którym ten przesłuchiwany się posługuje. ${ }^{8}$ Przy czym obowiązek ten

\footnotetext{
5 Zob. P. Hofmański, op.cit., s. 148.

6 Ustawa z 6.6.1997 r. - Kodeks postępowania karnego, Dz.U. Nr 89, poz. 555 z późn. zm. (dalej jako: k.p.k.).

7 Ustawa z 21.7.2001 r. - Prawo o funkcjonowaniu sądów powszechnych, Dz. U. Nr 98, poz. 1070, z późn. zm. (dalej jako: u.s.p.).

8 Zob. wyrok Sądu Najwyższego (SN) z 28.2.1978 r., I KR 12/78, OSNKW 1979, nr 9, poz. 148.
} 


\section{Joanna Dtugosz: Prawo do udziatu thumacza jako}

jedna z przestanek rzetelnego procesu karnego

istnieje zarówno wtedy, gdy osoba ta przesłuchiwana jest $\mathrm{w}$ charakterze pokrzywdzonego, jak i wówczas, gdy jest przesłuchiwana w charakterze świadka. 9

Warto przy tym podkreślić, że powyższy przepis wskazuje na obowiązek udziału w procesie karnym nie tylko tłumacza języka obcego, ale także każdego innego tłumacza, np. tłumacza języka migowego.

Abstrahując od sytuacji, wymienionych bezpośrednio w przepisie art. 204 k.p.k., w ramach procesu karnego istnieje szereg innych okoliczności procesowych, w których pomoc tłumacza musi być zapewniona, pomimo tego, iż brak jest odnośnego wskazania w przepisach ustawy. Chodzi tu przede wszystkim o takie ustawowe nakazy, które zobowiązują do udzielenia stronie procesowej jakiejkolwiek informacji. W charakterze przykładu można przywołać m.in. wynikający $\mathrm{z}$ art. $244 \S 2$ k.p.k. nakaz natychmiastowego poinformowania zatrzymanego o przyczynach zatrzymania i o przysługujących mu prawach oraz wysłuchania go, co, oczywiście, wymaga przede wszystkim umiejętności porozumienia się $\mathrm{z}$ tą osobą. Podobne zobowiązanie istnieje $\mathrm{w}$ przypadku czynności procesowych wykonywanych przy okazji ogłoszenia lub doręczenia orzeczenia. Art. $100 \S 6$ k.p.k. wymaga bowiem, aby po ogłoszeniu lub przy doręczeniu orzeczenia pouczyć uczestników postępowania o przysługującym im prawie, terminie i sposobie wniesienia środka zaskarżenia lub o tym, że orzeczenie nie podlega zaskarżeniu, do czego również niezbędna jest możliwość porozumienia się z inną osobą. ${ }^{10}$

\subsection{Regulacje ustawy - Prawo o funkcjonowaniu sądów powszechnych}

Regulacje prawne, odnoszące się do omawianej problematyki, zawarte są przede wszystkim $\mathrm{w}$ art. 5 wskazanej ustawy. Jak stanowi $\S 1$ tego przepisu, językiem urzędowym przed sądami jest język polski. Z uwagi jednak na to, że materiał dowodowy gromadzony jest także we wcześniejszych stadiach postępowania karnego, należy przyjąć, iż język polski uznawany jest za język urzędowy także przed innymi organami, takimi jak np. Policja czy prokuratura, które podejmuja czynności poprzedzające postępowanie przed sądem, tj. podjęte $\mathrm{w}$ ramach postępowania przygotowawczego.

Paragraf drugi powołanego przepisu stanowi natomiast, że osoba niewładająca $\mathrm{w}$ wystarczającym stopniu językiem polskim ma prawo do występowania przed sądem w znanym przez nią języku i do bezpłatnego korzystania z pomocy tłumacza. Wskazać przy tym należy, że przepis ten obejmuje wszystkich uczestników postępowania przed polskim sądem. ${ }^{11}$ Podkreślenia wymaga nadto, że niniejsza gwarancja - z jednej strony ujęta wprawdzie szerzej niż wskazany powyżej przepis Kodeksu postępowania karnego, stanowiąc chociażby, że korzystanie z pomocy tłumacza jest bezpłatne - dotyczy jedynie postępowania sądowego, nie obejmując swoim działaniem innych stadiów procesu karnego. ${ }^{12}$

\footnotetext{
${ }_{9}$ Szerzej na ten temat zob. S. Stachowiak, Uprawnienie pokrzywdzonego do korzystania z pomocy thumacza $w$ polskim procesie karnym, Prokuratura i Prawo 2000, Nr 12, s. 7 i nast.

${ }_{10}$ Dalsze przykłady zob. np. P. Hofmański, op.cit., s. 151.

11 Zob. S. Stachowiak, op.cit., s. 14.

${ }^{12} \mathrm{Na}$ ten temat szerzej por. P. Hofmański, op.cit., s. 151.
} 
Kolejnym aspektem wymagającym podniesienia jest fakt, że udział tłumacza w procesie karnym może wiązać się pewnymi utrudnieniami natury praktycznej. Problem pojawia się na przykład w momencie, gdy w okolicznościach danej sprawy nie jest możliwe bezpośrednie tłumaczenie na język polski (np. z uwagi na brak tłumacza władającego językiem polskim). Powstaje zatem pytanie czy można dokonać tłumaczenia za pośrednictwem kilku tłumaczy. Kwestia ta niejednokrotnie podnoszona była w doktrynie i orzecznictwie, w którym - mimo szeregu kwestii spornych - zasadniczo przyjęto, że w takich sytuacjach nie ma przeszkód, by tłumaczenie dokonywane było za pośrednictwem kilku tłumaczy. ${ }^{13}$

\section{Prawo do udziału tłumacza jako jeden $z$ elementów prawa do rzetelnego procesu karnego}

Omawiając problematykę udziału tłumacza, jako elementu prawa do rzetelnego procesu karnego, a tym samym jako jednego $\mathrm{z}$ praw oskarżonego $\mathrm{w}$ procesie karnym, należy zgodzić się z poglądem wyrażanym przez $P$. Hofmańskiego, iż kryterium decydującym o konieczności zapewnienia udziału tłumacza nie jest okoliczność, że oskarżony jest cudzoziemcem, ale to, że nie rozumie on i nie włada językiem używanym przez pracowników organów wymiaru sprawiedliwości. Możliwe są zatem sytuacje, w których tłumaczenie będzie niezbędne w stosunku do obywateli polskich, nieznających języka polskiego, natomiast nie będzie go potrzebował cudzoziemiec, który język polski rozumie i potrafi się $w$ nim wysłowić. ${ }^{14}$ Prawo do korzystania $\mathrm{z}$ pomocy tłumacza jest zatem jednoczenie elementem prawa do informacji. ${ }^{15}$

W praktyce potrzeba wezwania tłumacza do udziału w procesie pojawia się więc najczęściej wówczas, gdy oskarżony jest cudzoziemcem niewładającym językiem polskim lub władającym nim w taki sposób, iż organ procesowy nie jest w stanie precyzyjnie odczytywać przekazywanych przez osobę przesłuchiwaną (oskarżonego, podejrzanego lub świadka) treści.

\subsection{Gwarancje wynikające $z$ polskiego prawa karnego procesowego}

Przepisy Kodeksu postępowania karnego nie przewidują expressis verbis prawa niewładającego językiem polskim oskarżonego do korzystania z pomocy tłumacza. W tym kontekście pewne uregulowanie zawiera jedynie art. 72 k.p.k. w myśl którego oskarżony (a także podejrzany - por. art. $71 \S 3$ k.p.k.) ma prawo do korzystania z bezpłatnej pomocy tłumacza, jeżeli nie włada w wystarczającym stopniu językiem polskim (art. $72 \S 1$ k.p.k.). Tłumacza wzywa się również do wszystkich czynności z udziałem oskarżonego niewładającego w wystarczającym stopniu językiem polskim (art. $72 \S 2$ k.p.k.). Natomiast $\S 3$ zawiera gwarancję możliwości skutecznego zapoznania się z treścią doręczonych pism procesowych, stanowiąc że doręczenie oskarżonemu niewładającemu w wystarczającym stopniu językiem polskim pism procesowych zawierających postanowienie o przedstawieniu, uzupełnieniu lub zmianie zarzutów, akt oskarżenia, bądź też orzeczenie podlegające zaskarżeniu lub kończące postępowanie, następuje obligatoryjnie wraz z tłumaczeniem. Jednakże za zgodą oskarżonego można

13 Zob. wyrok Sądu Apelacyjnego w Krakowie z 18.1.1996 r., II Akr 343/95, przedrukowany w: Krakowskie Zeszyty Sądowe 1996, nr 1, poz. 32.

14 Tak P. Hofmański, op.cit., s. 148.

15 Zob. H. Kuczyńska, w: Rzetelny proces karny, pod red. P. Wilińskiego, Warszawa 2009, s. 166. 


\section{Joanna Dtugosz: Prawo do udziatu thumacza jako jedna z przestanek rzetelnego procesu karnego}

poprzestać na ogłoszeniu przetłumaczonego orzeczenia kończącego postępowanie, jeżeli nie podlega ono zaskarżeniu.

$\mathrm{Z}$ powyższej regulacji wynika zatem, że warunkiem realizacji przysługującego oskarżonemu prawa do skorzystania z pomocy tłumacza, jest fakt, iż nie włada on w wystarczającym stopniu językiem polskim, czyli nie posiada znajomości czynnej tego języka ${ }^{16}$. Kryterium przesądzającym o obowiązku wezwania tłumacza jest zatem jedynie stopień znajomości języka polskiego przez oskarżonego. Należy przy tym zauważyć, że prawo korzystania z pomocy tłumacza przysługuje oskarżonemu nie tylko w kontakcie z organami funkcjonującymi we wszystkich stadiach procesu karnego, ale także w kontaktach ze swoim obrońcą - i to także poza rozprawą sądową. ${ }^{17}$

\subsection{Zgodność polskich regulacji karnoprocesowych z tzw. międzynarodowym standardem minimalnym}

$\mathrm{W}$ odniesieniu do problematyki gwarancji udziału tłumacza, jako jednego z praw przysługujących podejrzanemu i oskarżonemu w procesie karnym, nie sposób nie wspomnieć chociażby krótko o przepisach prawa międzynarodowego, regulujących owe zagadnienie. ${ }^{18} \mathrm{~W}$ tym kontekście na uwagę zasługuje przede wszystkim wspomniana już regulacja art. $6 \mathrm{EKPC}$, normująca prawo do rzetelnego procesu sądowego i określająca tzw. karnoprocesowy standard minimalny, czyli minimum uprawnień procesowych, $\mathrm{z}$ których musi korzystać każdy oskarżony $\mathrm{w}$ postępowaniu karnym, bez względu na posiadane obywatelstwo. W odniesieniu do realizacji uprawnienia procesowego $\mathrm{w}$ postaci prawa do korzystania $\mathrm{z}$ pomocy tłumacza w postępowaniu karnym, w ustępie trzecim tego przepisu wskazuje się, że każdy oskarżony o popełnienie czynu zagrożonego karą ma co najmniej prawo do niezwłocznego otrzymania szczegółowej informacji $\mathrm{w}$ języku dla niego zrozumiałym o istocie i przyczynie skierowanego przeciwko niemu oskarżenia oraz do korzystania z bezpłatnej pomocy tłumacza, jeżeli nie rozumie lub nie mówi językiem używanym w sądzie. ${ }^{19}$ Podobnie zatem, jak to reguluje art. 72 k.p.k., wyznacznikiem obowiązku urzeczywistnienia tego prawa jest stopień znajomości

\footnotetext{
${ }^{16} \mathrm{~W}$ przeciwieństwie do znajomości biernej, której brak należałoby wrazić używając sformułowania „kto nie rozumie”. W tym kontekście należałoby wskazać na dwa prawa, które przysługiwały oskarżonemu na gruncie przepisów k.p.k. obowiązujących do zmiany Kodeksu postępowania karnego w 2003 roku (por. ustawa z 10.1.2003 r. o zmianie ustawy - Kodeks postępowania karnego, ustawy - Przepisy wprowadzające Kodeks postępowania karnego, ustawy o świadku koronnym oraz ustawy o ochronie informacji niejawnych, Dz. U. Nr 17, poz. 155), tj. na ówcześnie obowiązujący art. $79 \S 1$ pkt 4 k.p.k., zgodnie z którym w postępowaniu karnym oskarżony musiał mieć obrońcę, jeżeli nie władał językiem polskim oraz na art. 407 k.p.k., który wskazywał, iż w końcowej fazie rozprawy przed sądem oskarżonemu, który nie włada językiem polskim, należy przed udzieleniem głosu przetłumaczyć przynajmniej skrót przemówień.

${ }^{17}$ Zob. np. B. Zygmont, op.cit., s. 80.

${ }^{18}$ Szerzej na ten temat zob. C. Nowak, Prawo do korzystania z pomocy thumacza $w$ europejskim $i$ polskim prawie karnym, Prokuratura i Prawo 1998, Nr 10, s. 89 i nast.; B. Zygmont, op.cit., s. 76 i nast.

19 Szerzej na ten temat zob. P. Hofmański, op.cit., S. 151 i nast. Warto wskazać także na dwa kryteria, sformułowane przez Europejski Trybunał Praw Człowieka (ETPC), których alternatywne spełnienie uzasadnia możliwość skorzystania z bezpłatnej pomocy tłumacza, tj.: oskarżony nie jest w stanie pojąć znaczenia i sensu czynności dokonywanych w jego sprawie lub oskarżony nie jest $\mathrm{w}$ stanie wysłowić się w języku sądu; zob. szerzej wyrok ETPC z 21.2.1984 r., 8544/79, Öztürk v. Niemcy, § 40 .
} 
języka. ${ }^{20}$ Należy jednak podkreślić, że obowiązek wezwania tłumacza nie rozciąga się na osoby, które znając i rozumiejąc język używany w sądzie, z różnych powodów odmawiają jego używania. ${ }^{21}$

Wartym wzmianki jest nadto zakres normowania omawianego przepisu art. 6 ust. 3 lit. e Konwencji. Wykładnia literalna tej regulacji mogłaby bowiem prowadzić do konkluzji, że prawo do bezpłatnej pomocy tłumacza przysługuje tylko $\mathrm{w}$ postępowaniu sądowym. Należy wszelako zgodzić się $\mathrm{z}$ przyjętym $\mathrm{w}$ orzecznictwie poglądem, że gwarancja ta przysługuje także podejrzanemu $\mathrm{w}$ postępowaniu przygotowawczym. ${ }^{22}$ Dokonując zatem porównania zakresu normowania omawianej regulacji z przepisem art. 72 k.p.k. zauważyć należy, iż wskazany w Konwencji standard minimalny uprawnień procesowych został w tym zakresie w pełni uwzględniony w polskich przepisach karnoprocesowych.

Analizowany przepis Konwencji gwarantuje nadto, że pomoc tłumacza ma być bezpłatna ${ }^{23}$. Już pobieżna analiza przepisów krajowych prowadzi do wniosku, że Kodeks postępowania karnego uwzględnia ten wymóg jedynie w ograniczonym zakresie, tj. tylko w stosunku do oskarżonego. Art. 619 § 3 k.p.k. stanowi bowiem, że Skarb Państwa ponosi koszty związane $\mathrm{z}$ udziałem tłumacza $\mathrm{w}$ zakresie koniecznym dla zapewnienia oskarżonemu jego prawa do obrony. Natomiast $\mathrm{w}$ innych przepisach działu XVI k.p.k., regulującego koszty procesu mowa jest jedynie o tym, że należności tłumaczy, stanowiące wydatki Skarbu Państwa należą do kosztów procesu, które ponosi oskarżony w wypadku jego skazania, a także w razie warunkowego umorzenia postępowania. ${ }^{24}$ Abstrahując od tego, że wskazane regulacje kodeksowe częściowo nie uwzględniają standardów zawartych w Konwencji ${ }^{25}$, to dodatkowo niezgodne są z art. $5 \S 2$ u.s.p., który gwarantuje osobie niewładającej $\mathrm{w}$ wystarczającym stopniu językiem polskim prawo do bezpłatnego korzystania przed sądem z pomocy tłumacza.

\section{Zakończenie i postulaty de lege ferenda}

Reasumując należy stwierdzić, że w zakresie realizowania prawa do rzetelnego procesu karnego organy procesowe powinny angażować tłumaczy zawsze wówczas, gdy przemawia za tym interes oskarżonego, a w szczególności pełna i kompleksowa realizacja przysługujących mu w procesie praw. Oznacza to, że nie jest konieczne w każdych okolicznościach pisemne przełożenie całych akt danej sprawy, lecz za wystarczające należy uznać dokonanie tego jedynie $\mathrm{w}$ zakresie niezbędnym do zapewnienia oskarżonemu rzetelnego procesu. ${ }^{26}$ A zatem, należy mieć na uwadze, że prawo do korzystania $\mathrm{z}$ pomocy tłumacza powinno przysługiwać $\mathrm{w}$ takim zakresie, w jakim jest to konieczne dla zapewnienia elementarnych gwarancji procesowych osobie, przeciwko której podjęto czynności nakierowane na jej

\footnotetext{
${ }^{20}$ Zob. także C. Nowak, w: Rzetelny proces karny, pod red. P. Wilińskiego, Warszawa 2009, s. 132 i nast.

${ }^{21}$ Zob. decyzja Komisji z 7.12.1983 r., 10210/82, K v. Francja oraz z 6.10.1986 r., 11261/84, Bideault v. Francja.

${ }^{22}$ Zob. wyrok ETPC z 19.12.1989 r., 9783/82, Kamasinski v. Austria, § 64; a także. P. Hofmański, op.cit., s. 152 oraz wskazane tam piśmiennictwo.

${ }_{23}$ Zob. wyrok ETPC z 1.3.2006 r., 56581/oo, Sjedovic v. Włochy, § 89.

24 Por. art. 616, 618 § 1 pkt 7, 627, 629 k.p.k.

25 Zob. np. wyrok ETPC z 28.11.1978 r., 6210/73, Luedicke, Belkacem and Koç v. Niemcy, § 40.

${ }^{26}$ Zob. także wyrok ETPC z 19.12.1989 r., 9783/82, Kamasinski v. Austria, § 74.
} 


\section{Joanna Dtugosz: Prawo do udziatu thumacza jako jedna z przestanek rzetelnego procesu karnego}

ściganie $\mathrm{z}$ powodu podejrzenia popełnienia czynu zabronionego. Rozstrzygający powinien być przeto interes tej osoby, a nie interes wymiaru sprawiedliwości. ${ }^{27}$

Nadto należy podnieść, iż ze względu na to, że Konwencja o Ochronie Praw Człowieka i Podstawowych Wolności - w świetle art. 91 ust. 1 Konstytucji RP stanowi część krajowego porządku prawnego i jest bezpośrednio stosowana, organy postępowania karnego powinny w pełni uwzględniać wynikające $\mathrm{z}$ niej standardy. Oznacza to zobowiązanie do zapewnienia osobom niewładającym w wystarczającym stopniu językiem polskim skuteczniejszych gwarancji korzystania z bezpłatnej pomocy tłumacza, niż to wynika z obowiązujących regulacji Kodeksu postępowania karnego. W tym kontekście podnieść należy także konieczność istotnej korekty - i to nie tylko w świetle niezgodności z ratyfikowaną Konwencją, ale również i niespójności pomiędzy normami prawa krajowego - kwestii ponoszenia koszów za korzystanie z pomocy tłumacza.

W zakończeniu wskazać należy jeszcze na jedną kwestię, niejednokrotnie pojawiającą się w zarówno orzecznictwie, jak i projektowanych aktach prawnych na płaszczyźnie międzynarodowej; mianowicie, że obowiązki państwa w będącej przedmiotem niniejszego opracowania materii nie ograniczają się jedynie do obowiązku ustanowienia tłumacza, ale także do zagwarantowania jego odpowiednich kwalifikacji i tłumaczenia dokumentów procesowych w taki sposób, by oskarżony rozumiał postawione mu zarzuty oraz przebieg postępowania. Nie budzi najmniejszych wątpliwości, że obejmują one również umożliwienie w określonych okolicznościach kontroli jakości tłumaczenia. ${ }^{28}$

\section{Bibliografia}

Hofmański, P. 2000. Prawo do udziału tłumacza w postępowaniu karnym. w: A.J. Szwarc (Ed.) Przestępczość przygraniczna. Postępowanie karne przeciwko cudzoziemcom $w$ Polsce. Poznań: Wydawnictwo Poznańskie. pp. 147-156.

Kuczyńska, H. 2009. w: P. Wiliński (Ed.) Rzetelny proces karny. Warszawa: Wolters Kluwer. pp. 166.

Nowak, C. 1998. Prawo do korzystania z pomocy tłumacza w europejskim i polskim prawie karnym, Prokuratura i Prawo, vol. 10, pp. 89 et seqq.

Nowak, C. 2009. w: P. Wiliński (Ed.) Rzetelny proces karny. Warszawa: Wolters Kluwer. pp. 132 et seqq.

Stachowiak, S. 2000. Uprawnienie pokrzywdzonego do korzystania z pomocy tłumacza w polskim procesie karnym, Prokuratura i Prawo, vol. 12, pp. 7 et seqq.

Zygmont, B. 2004. Prawo do korzystania z bezpłatnej pomocy tłumacza w postępowaniu karnym w świetle standardów europejskich, Państwo i Prawo, vol. 7, pp. 78.

\footnotetext{
27 Por. P. Hofmański, op.cit., s. 153.

${ }_{28}$ Zob. wyrok ETPC z 19.12.1989 r., 9783/82, Kamasinski v. Austria, § 74, a także projekt decyzji ramowej Rady $\mathrm{w}$ sprawie niektórych praw proceduralnych $\mathrm{w}$ postępowaniu karnym $\mathrm{w}$ Unii Europejskiej, COM (2004) 318.
} 